\title{
M. leprae Infection of Vascular and Lymphatic Endothelial Cells of the Epineurium and Perineurium in Experimental Lepromatous Neuritis
}

\author{
David M. Scollard* \\ Department of Research Pathology, GWL Hansen's Disease Center at LSU, Baton Rouge, LA., \\ and Department of Pathology, Louisiana State University School of Medicine, New Orleans, LA.
}

[Received: 5 October 1999]

Key words: Peripheral nerve, Lepromatous neuritis, Endothelial cells, Experimental leprosy, M.leprae-endothelium adhesion

Infection of peripheral nerve by $M$. leprae, the histopathologic hallmark of leprosy, is a major factor in this disease, but the route and mechanisms by which bacilli localize to peripheral nerve are unknown. Experimentally infected armadillos have recently been recognized as a model of lepromatous neuritis; the major site of early accumulation of $M$. leprae is epineurial. To determine the epineurial cells involved, $1 \mathrm{~cm}$. segments of 44 nerves from armadillos were screened for acid-fast bacilli (AFB), and thin sections were examined ultrastructurally. Of 596 blocks containing nerve, 36\% contained AFB. Overall, M. leprae were found in endothelial cells in $40 \%$ of epineurial blood vessels and $75 \%$ of lymphatics, and in $25 \%$ of endoneurial vessels.

Comparison of epineurial and endoneurial findings suggested that colonization of epineurial vessels preceded endoneurial infection. Such colonization of epineurial nutrient vessels may greatly increase the risk of endoneurial $M$. leprae bacteremia, and also enhance the risk of ischemia following even mild increases in inflammation or mechanical stress. These findings also raise the possibility that early, specific mechanisms in the localization of M. leprae to peripheral nerve may involve adhesion events between M. leprae (or M. lepraeparasitized macrophages) and the endothelial cells of the vasa nervorum.

The histopathologic hallmark of leprosy is the infection of peripheral nerves by M. leprae, the only bacterial pathogen with this unique tropism ${ }^{1)}$. The resulting injury to peripheral nerves causes the loss of sensation and paralysis which are major clinical features of leprosy ${ }^{2)}$. These neuropathic changes are

\footnotetext{
*Corresponding author :

Chief, Research Pathology

GWL Hansen's Disease Center at LSU

Baton Rouge, LA

e-mail: dscoll1@1su.edu

Tel: 225-346-5769 Fax: 225-346-5786
}

responsible for the deformities that elicit most of the stigma and opprobrium which are the social hallmarks of this disease ${ }^{3)}$.

A century ago, full-length dissections of peripheral nerves at autopsy revealed an ascending degeneration of nerves with interstitial inflammation and perineurial thickening, which were greatest near the cutaneous lesion and declined proximally. This demonstrated that the distal anesthesia and motor deficits in leprosy are due to peripheral neuropathy ${ }^{5,6)}$. 
Since that time, however, little progress has been made in understanding the mechanisms of nerve injury in leprosy, largely because investigations have depended entirely on studies of biopsies of human nerves, due to the lack of an animal model. Such studies have necessarily been almost entirely limited to small biopsies of the radial cutaneous and sural nerves which will leave minimal sequelae, even when these are not major sites of clinical neuropathy.

Experimental infection of nine-banded armadillos (Dasypus novemcinctus) with $M$. leprae is now well recognized as a model of lepromatous disease ${ }^{6-8)}$ and the infection of peripheral nerves in these animals has been described briefly ${ }^{9,10)}$. However, we have recently determined that the $M$. leprae-infected armadillo develops an extensive neuritis which is very similar to that of human lepromatous leprosy, and is a true animal model of neuritis in this disease ${ }^{11}$. Unlike previous attempts to develop animal models by inoculating $M$. leprae directly into nerves or inducing nerve localization by means of trauma ${ }^{12,13)}$, no effort is made in the armadillo to direct the organisms to nerves. Instead, this model recapitulates the unique natural localization of M. leprae to non-traumatized peripheral nerves.

The initial observations in this model indicated that the intensity of $M$. leprae infection in the tissues on the surface of nerves was greater than in the endoneurial compartment ${ }^{11)}$. This suggested that localization of $M$. leprae to peripheral nerves might be mediated by cells and eventos occurring in the epineurium. We therefore examined the epineurium of infected armadillo nerves in detail, in order to determine the types of cells and structures that are infected.

\section{MATERIALS AND METHODS}

Animals. Eight adult, nine-banded armadillos were inoculated intravenously with $3-4 \times 10^{8} \mathrm{M}$. leprae, freshly obtained from other experimentally infected armadillos or nude mice, as described previously ${ }^{11,14)}$. After 12-18 months, when widespread dissemination of the infection had developed, animals were anesthetized and sacrificed by exsanguination.

Nerve fixation and processing. The distal $1 / 2$ to $2 / 3$ of major peripheral nerve trunks in each extremity were dissected and placed in cold fixative, as described previously ${ }^{15}$. Each nerve was divided into $1 \mathrm{~cm}$ lengths, post-fixed in osmium tetroxide, dehydrated and embedded as described ${ }^{15}$. Semithin $(1.5 \mu)$ sections were cut on a diamond knife, stained for acid fast-bacilli ${ }^{16)}$, and screened by light microscopy to identify blocks containing acid-fast organisms. Ultrathin sections ( $90-100 \mathrm{~nm}$ ) were stained with uranyl acetate and lead citrate and were examined and photographed with a Philips 410 electron microscope. Epineurial blood vessels and lymphatics in each cross-section were examined and the number with and without $M$. leprae in their endothelial cells was recorded. The number of infected and uninfected endoneurial blood vessels was similarly determined in cross-sections.

Overall epineurial inflammation and bacillary load were assessed on a semi-quantitative scale of $1+-3+$ as follows: $1+,<10$ bacilli or minimal mononuclear cell infiltration; $2+, 11-50$ bacilli or moderate cellular infiltrate; $3+,>50$ bacilli or heavy inflammation.

\section{RESULTS}

A total of 44 separate nerves were examined from eight armadillos (Table). Mild, focal thickening was observed grossly in many specimens. Of 596 blocks containing peripheral nerve, M. leprae were found in semi-thin sections of 215 , and bacilli were located in the epineurium in $86 \%$ of these. The extent of infection and inflammation of nerves varied greatly in different animals. In most nerves focal lesions were separated by intervals of normal nerve.

Mild to severe thickening of the epineurium and perineurium was observed at many foci of $M$. leprae infection, involving several components of the 
epineurium (Fig. 1a). Infection of vascular and lymphatic endothelial cells by $M$. leprae was a prominent finding on ultrastructural examination (Fig. 1b, c), typically involving only one or two organisms per endothelial cell. The interstitial infiltrates on the epineurial surface were composed primarily of macrophages, many of which were infected and which contained the majority of the acid-fast organisms observed by light microscopy. The fibrous layers of the epineurium were thickened and filbroblasts were focally infected with $M$. leprae. Mononuclear leukocytes were also frequently observed at sites of inflammatory thickening of just beneath the epineurium (Fig. 1b).

At sites of moderate to heavy mycobacterial infection, mononuclear leukocytes were often observed forming a perivascular "cuff" around vessels in the epi- or perineurium (Fig. 2). Such cuffing primarily consisted of macrophages, infected and uninfected, which had accumulated around vessels with either infected or uninfected endothelial cells.

Lymphatics on the surface of the epineurium were frequently also distended with infected monocytes (Fig 3a). Lymphatic endothelial cells were of- ten heavily infected, and $M$. leprae were sometimes observed extracellularly within the lymphatic lumen (Fig. 3a). Some lymphatic endothelial cells had extracellular M. leprae attached to them (Fig. 3b), while others had infected monocytes attached (Fig. 3c).

Infection of epineurial endothelial cells was observed in $17 \%$ of vascular and $24 \%$ of lymphatic vessels in foci of lighter infection (Fig. 4). The frequency of infection increased to $50 \%$ and $82 \%$, respectively, in foci of high intensity inflammation and infection. In endoneurial vessels, the frequency of endothelial cell infection was lower in all groups but also increased from $10 \%$ to $39 \%$ in low and high intensity sites of inflammation, respectively (Fig. 4). The difference between groups was significant in all cases $(p=0.001-0.002)$, and increases in endoneurial endothelial cell infection followed increases in epineurial endothelial cell infection in all groups.

\section{DISCUSSION}

This report presents the first detailed study of major peripheral nerves during active lepromatous

Table. Peripheral nerves studied in experimentally infected armadillos.

\begin{tabular}{|cccc|}
\hline & $\begin{array}{c}\text { Number of } \\
\text { Armadillo }\end{array}$ & $\begin{array}{c}\text { Total Number } \\
\text { Nerves Studied }\end{array}$ & $\begin{array}{c}\text { of Sections } \\
\text { \% Positive }\end{array}$ \\
\hline 1 & 4 & 29 & 3.4 \\
3 & 4 & 38 & 15.8 \\
4 & 4 & 64 & 26.6 \\
5 & 4 & 76 & 36.8 \\
6 & 4 & 73 & 67.1 \\
7 & 8 & 109 & 4.6 \\
8 & 8 & 91 & 18.7 \\
\hline \hline Total & 8 & 116 & 77.6 \\
\hline \hline
\end{tabular}


neuritis. The results indicate that 1) the endothelial cells of epineurial lymphatics and blood vessels are heavily colonized by $M$. leprae; 2) endothelial cells of endoneurial blood vessels also carry a substantial bacterial load, even in early foci of infection; and 3) as the overall bacterial load around the nerve increases, the bacterial load of both epineurial and endoneurial endothelial cells also increases. The endoneurial compartment is thus continuously at risk

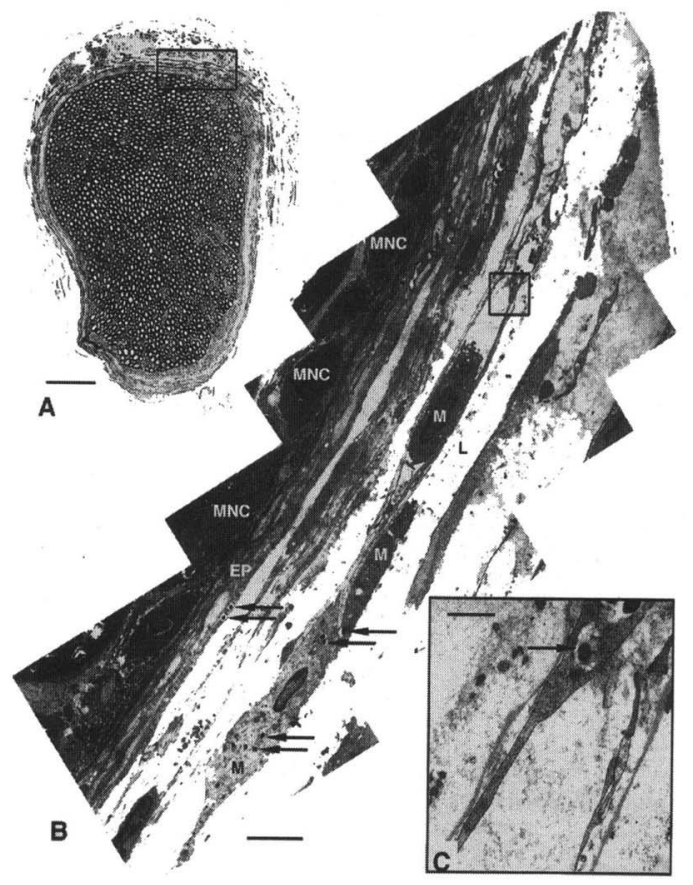

Fig. 1. Epineurial thickening with M. leprae infection of interstitial macrophages and lymphatic and vascular endothelial cells.

A. Inflammatory thickening of the epineurium is seen at the top and bottom of this $1.5 \mathrm{~mm}$ cross section of the right superficial peroneal nerve. (Toluidine blue stain; bar $=100 \mathrm{~mm}$ ).

B. Ultrastructural examination of the enclosed area in ' $A$ ' revealed heavily infected interstitial macrophages (M) heavily infected with $M$. leprae (arrows), as well as infection of vascular endothelial cells (box) and adjacent lymphatics (L). The fibrous layers of the epineurium (EP) are slightly thickened and a small number of bacilli are also seen within them. Mononuclear leukocytes (MNC) are also seen just beneath the epineurium. (Digital photo-montage; $\mathrm{Bar}=5 \mathrm{~mm}$ )

C. Enlargement of the enclosed area in ' $\mathrm{B}$ ' reveals the typical ultrastructural appearance of $M$. leprae with its clear zone, lying within a vascular endothelial cell. $($ Bar $=1 \mathrm{~mm})$ of infection.

The findings in this experimental model bring together several well-documented histopathologic elements of leprosy that have not been integrated in theories of the pathogenesis of neuritis: perineurial proliferation and infection, infection of lymphatic endothelial cells, and infection of vascular endothelial cells.

Infection of vascular endothelial cells has been



Fig. 2. Perivascular cuffing by infected and uninfected macrophages. Macrophages are seen surrounding a small epineurial blood vessel. The three endothelial cells are swollen, and although infection was present nearby, neither the endothelial cells nor the macrophages contain bacilli at the level of this section. (Bar $=5 \mathrm{~mm}$ ) 
reported several times, starting with the original descriptions of Hansen and Looft in $1895^{17-21)}$, and has been regarded as evidence of hematogenous dissemination of M. leprae. Several reports have emphasized the presence of $M$. leprae infection of endoneurial vascular endothelial cells ${ }^{22,23)}$, as well as those in the epi- and perineurium ${ }^{24}$. However, the observation of frequent, substantial endothelial cell infection, with increasing frequency in

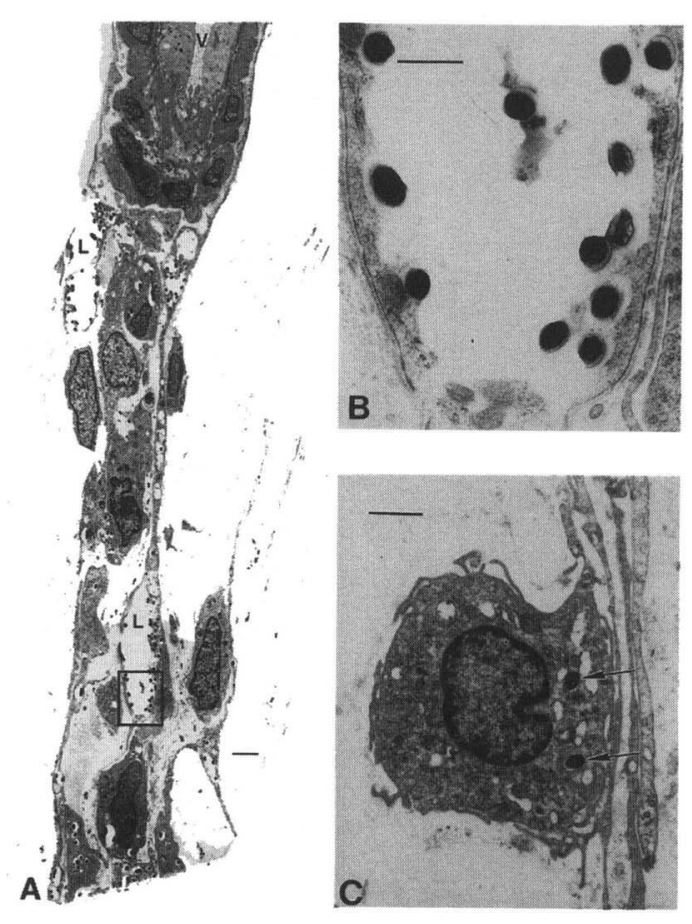

Fig. 3. Infection of epineurial lymphatics by $M$. leprae.

A. A large number of intra-luminal bacilli are seen within the lumina of lymphatic vessels (L). Many of these are adherent to endothelial cells and appear to be free (not intracellular). No bacilli are seen in the endothelium of the large blood vessel at the upper end of the photo $(\mathrm{V})$, but a perivascular cuff of mononuclear cells is present. (Digital photo-montage; bar $=2 \mathrm{~mm}$ )

B. Enlargement of the area enclosed in "A" shows extracellular M. leprae in the lumen of a lymphatic vessel, adherent to the endothelium. (Bar $=0.5 \mathrm{~mm}$ )

C. A circulating monocyte, infected with $M$. leprae (arrows), has attached to the luminal surface of an endothelial cell. $($ Bar $=1 \mathrm{~mm})$ endoneurial endothelium following increases in epineurial endothelium, provides the most direct evidence to date that $M$. leprae gain access to the endoneurial compartment via its blood supply. This is consistent with previous reports 9, 25,26), and supports the suggestion that $M$. leprae reaches the endoneurial compartment by hematogenous spread 2. 27). The perivascular cuffing of infected and uninfected macrophages, also noted previously ${ }^{25}$, suggests emigration of these cells from nutrient epineurial vessels.

Involvement of lymphatic vessels has been less thoroughly examined in leprosy, although it has also been proposed that $M$. leprae might reach nerves via epineurial lymphatics ${ }^{27-29)}$.

Lymphatic endothelial cells appear to be a major reservoir of M. leprae on the surface of the nerve, and these infected lymphatics may also provide a source for infection of the adjacent vascular plexus. Drainage along epineurial lymphatics may also partially explain the interstitial and epineurial inflammation described in autopsy dissections ${ }^{5,6)}$.

Perineurial infection and inflammation have been recognized as characteristic features of cutaneous leprosy lesions since they were described in the earliest histopathologic reports ${ }^{17,30)}$. These changes have generally been viewed as late consequences and of less important than the unique infection of Schwann cells by $M$. leprae, in the theory of pathogenesis (noted above) which proposes that direct axonal or Schwann cell infection is the primary event. Thus one review concluded that perineurial involvement occurs "only much later" than endoneurial infection and inflammation ${ }^{31)}$, and the presence of M. leprae in the perineurium and epineurium of cutaneous nerves in lepromatous leprosy has usually been interpreted as a 'breakout' of bacilli ${ }^{32)}$, 'bursting out from a nerve bundle to perineurial macrophages' ${ }^{33)}$.

Our findings provide a substantial basis for a different explanation of the pathogenesis of nerve involvement in leprosy. Contrary to the long-held opinion that $M$. leprae enter nerves at distal sites, where Schwann cells may be exposed, and travel 
centripetally within nerves through axons or Schwann cells $^{5,34,35)}$, we propose that $M$. leprae colonizes the epineurial blood vessels and through their branches enter the endoneurium, after which Schwann cells ingest them.

Because Schwann cells are isolated behind the highly protective barrier of the perineurium, the only access to them in a normal, non-traumatized nerve is via the blood vessels which enter the endoneurial compartment. There is no evidence that trauma precedes the infection of peripheral nerves by $M$. leprae.
Therefore, mechanisms which do not directly involve the Schwann cell but may involve the neurovascular endothelium may play major roles in the tropism of $M$. leprae to peripheral nerve.

The high prevalence of $M$. leprae infection of epineurial and perineurial endothelial cells has several important implications for the pathogenesis of nerve injury in leprosy. First, by colonizing the vascular and lymphatic endothelial cells in the plexus of vessels on the epineurium, a reservoir is created which favors infection of the endoneurium through

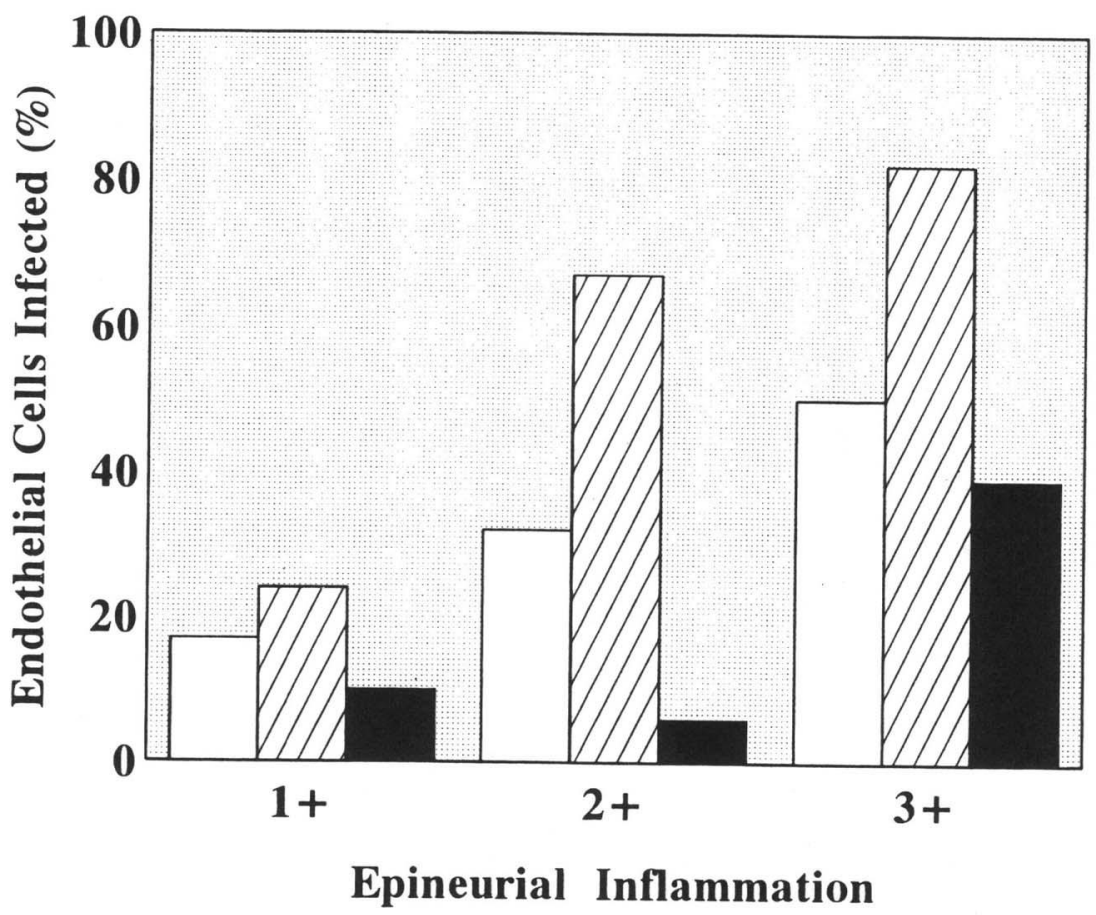

Fig. 4. Infection of endothelial cells in the epineurium and endoneurium at sites of mild to severe epineurial thickening and inflammation. Severity of overall epineurial thickening was graded on a scale of $1+-3+$, as described in the text. The percentage of endothelial cell infection identified ultrastructurally is indicated for epineurial vascular EC (open bars), epineurial lyphatic EC (hatched bars), and endoneurial vascular EC (solid bars). Lymphatic EC infection predominated at all degrees of overall thickening, and as the prevalence of epineurial EC infection increased, so did the prevalence of endoneurial EC infection. 
its blood supply. This may partially explain the predilection of this pathogen to peripheral nerves, which comprise a very small percentage of total body mass.

Second, the risk of ischemia of the underlying nerve following even a mild increase in inflammation, trauma, or mechanical stress may be greatly enhanced by the extensive perivascular colonization of the epineurium and infection of the endothelium. Such ischemia, either episodic and transient or chronic and persistent, may be a major factor in the overall development of neuropathy in this disease ${ }^{31}$, reviewed in 36).

Finally, these findings raise previously unrecognized possibilities that an early, specific step in the localization of $M$. leprae to peripheral nerve may be mediated by adhesion events between $M$. leprae (or $M$. leprae-parasitized macrophages) and the endothelial cells of the vasa nervorum. Endothelial cells in many tissues are known to express specific molecular addressins, responsible for the selective binding and retention of leukocytes with complementary ligands ${ }^{37)}$. It is possible that endothelial cells associated with peripheral nerve have such a molecular addressin which could facilitate the unique accumulation of M. leprae or M. leprae-infected macrophages in these vessels.

\section{ACKNOWLEDGEMENTS}

The author is deeply indebted to Greg McCormick and Joe Allen for excellent technical assistance, to Dr. Richard Truman and the staff of the Microbiology Research Department for access to armadillo tissues and histories, and to Mrs. Penne Cason for assistance in preparation of the manuscript.

\section{REFERENCES}

1) Clements BR and Scollard DM: Leprosy. Atlas of Infectious Diseases. Edited by Mandell GL and Fekety R. Philadelphia, Current Medicine, Vol 8 Chapter 9 (1996).

2) Sabin TD, Swift TR and Jacobson RR: Leprosy.
Peripheral Neuropathy, Third Edition, Edited by Dyck PJ and Thomas PK. Philadelphia, WB Saunders, Chapter 74 (1993).

3) Skinsnes OK: Leprosy in Society. III. The Relationship of the Social to the Medical Pathology of Leprosy. Leprosy Review 35:175-181 (1964).

4) Gerlach W: Investigations on anaesthetic skin patches. Virchow's Archiv. 125: 126-145 (1891).

5) Dehio K: On the Lepra Anesthetica and the pathogenetical relation of its disease-appearances. Proceedings of the International Scientific Leprosy Conference in Berlin, Oct., 1897, translated and reprinted in Leprosy in India 24:78-83 (1952).

6) Storrs EE: The nine-banded armadillo, a model for leprosy and other biomedical research. Int $\mathrm{J}$ Lepr. 39:703-714 (1971).

7) Kirchheimer WF, Storrs EE and Binford $\mathrm{CH}$ : Attempts to establish the armadillo (Dasypus novemcinctus) as a model for leprosy. 2. Histopathologic and bacteriologic post-mortem findings in lepromatous leprosy in the armadillo. Int J Lepr. 40:229-242 (1972).

8) Job CK, Sanchez RM and Hastings RC: Manifestations of experimental leprosy in the armadillo Dasypus novemcinctus. Am J Trop Med Hyg. 34:151-161 (1985).

9) Yoshizumi MO, Kirscheimer WF and Asbury AR: A light and electron microscopy study of peripheral nerves in an armadillo with disseminated leprosy. Int J Lepr. 42:251-9 (1974).

10) Balentine JD, Chang SC and Issar SL: Infection of armadillos with $M$. leprae: Ultrastructural studies of peripheral nerve. Arch Pathol Lab Med. 100:175-181 (1976).

11) Scollard DM, Lathrop GW and Truman RW: Infection of distal peripheral nerves by M. leprae in infected armadillos; an experimental model of nerve involvement in leprosy. Int J Lepr. 64:146-151 (1996).

12) Mshana RN, Humber DP, Harboe M and Belehu A: Nerve damage following intraneural injec- 
tion of $M$. leprae into rabbits pre-sensitized to mycobacteria. Clin Exp Immunol. 52:441-448 (1983).

13) Rassouli I and Mehta LN: Reaction of peripheral nerves to vascular and bacterial injuries. Indian J Lepr. 64:14-27 (1992).

14) Scollard DM and Truman RW: The Armadillo Leprosy Model, With Particular Reference to Lepromatous Neuritis. Handbook of Animal Models of Infection. Edited by Zak O \& Sande M. Academic Press, In press

15) Scollard, DM, and McCormick, G, and Allen, $\mathrm{JL}$ : Localization of Mycobacterium leprae to endothelial cells of epineurial and perineurial blood vessels. Am. J Pathol. 154: 1611-1620 (1999).

16) Luderschmidt $C$ : Orientation staining for the demonstration of $M$. leprae in semithin sections. Int J Lepr. 55:83-87 (1987)

17) Hansen GA and Looft C: Leprosy in its Clinical and Pathological Aspects, 1895. Transl. by Norman Walker, Bristol, John Wright \& Co., London (1973).

18) Fite, G.L. The vascular lesions of leprosy. Int. J. Lepr. 9: 193-202 (1941).

19) Coruh G and McDougall AC: Untreated lepromatous leprosy: Histopathological findings in cutaneous blood vessels. Int J Lepr. 47:500-501 (1979).

20) Turkel SB, Van Hale HM and Rea TH: Ultrastructure of the dermal microvasculature in leprosy. Int J Lepr. 50:164-181 (1982).

21) Burchard PJ and Bierther M: An electron microscopic study of small cutaneous vessels in lepromatous leprosy. Int J Lepr. 53:70-74 (1985).

22) Job CK: $M$. leprae in nerve lesions in lepromatous leprosy. Arch Pathol. 89: 195-207 (1970).

23) Dastur DK, Ramamohan Y and Shah JS: Ultrastructure of lepromatous nerves. Int J Lepr. 41:47-80 (1973).

24) Chimelli L, Freitas $M$ and Nascimento $O$ : Value of nerve biopsy in the diagnosis and follow-up of leprosy: the role of vascular lesions and use- fulness of nerve studies in the detection of persistent bacilli. J Neurol. 244:318-323 (1997).

25) Boddingius J: Ultrastructural and histophysiological studies on the blood-nerve barrier and perineurial barrier in leprosy neuropathy. Arch Neuropathol (Berl). 64:282-296 (1984).

26) Mukherjee A and Meyers WM: Endothelial cell bacillation in lepromatous leprosy; a case report. Lepr Rev. 58: 419-424 (1987).

27) Skinsnes OK: M. leprae and its "affinity" for nerves. Int J Lepr. 39:762-765 (1971)

28) Khanolkar VR: Perspectives in pathology of leprosy. Indian J Med Sci. 9 (Suppl): 1-44 (1952).

29) Mukherjee A, Misra RS and Meyers WM: An electron microscopic study of lymphatics in the dermal lesions of human leprosy. Int J Lepr. 57:506-510 (1989).

30) Virchow R: (1882) Quoted in editorial notes. Lepr India 24:35-46 (1952).

31) Sunderland S: The internal anatomy of nerve trunks in relation to the neural lesions of leprosy. Brain 96:865-888 (1973).

32) Ridley DS: Skin Biopsy in Leprosy. Documenta Geigy, Basle. Ciba-Geigy (1977).

33) jHarada K: Biopsy of Skin Lesions in Leprosy. Natinoal Sanitorium Tamazenseiyen, Tokyo, Japan (1995).

34) Lumsden CE: Leprosy and the Schwann Cell in vivo and in vitro. Leprosy in Theory and Practice. Edited by Cochrane RG and Davey TS. Bristol, John Wright \& Sons, 1964, Chapter 13, pp 221-150 (1964).

35) Khanolkar VR: Pathology of Leprosy. Leprosy in Theory and Practice. Edited by Cochrane RG and Davey TF. Bristol, John Wright \& Sons, Ch 8, pp 125-151 (1964).

36) Carayon A: Investigations on the pathophysiology of the nerve in leprosy. Int J Lepr. 39:278294 (1971).

37) Bevilacqua MP: Endothelial-leukocyte adhesion molecules. Ann Rev Immunol. 11:767-804 (1993). 


\title{
実験的らい性神経炎における神経上、周膜血管 およびリンパ管内皮細胞のらい菌感染
}

\author{
David M. Scollard \\ Department of Research Pathology, GWL Hansen's Disease Center at LSU, Baton Rouge, LA., \\ and Department of Pathology, Louisiana State University School of Medicine, New Orleans, LA.
}

〔受付：1999年 10 月 5 日〕

キーワード : 末梢神経、らい性神経炎、内皮細胞、実験的ハンセン病、らい菌一内皮細胞接着

らい菌の末梢神経感染はハンセン病の組織病理学的診断の決め手であり、本疾患の最重要課題で あるにもかかわらず、その経路と菌局在のメカニズムが分かっていない。一方、実験的らい菌感染 アルマジロはらい性神経炎のモデルとして近年注目されて来た。モデルではらい菌の早期主要局在 部位は神経周膜である。そこで、らい菌局在に関係する周膜細胞を確認するため神経の毎 $1 \mathrm{~cm} の$ 44 組織片について抗酸菌を識別し、電子顕微鏡で検討した。

結果は 596 組織片の $36 \%$ に抗酸菌を認め、らい菌は $40 \%$ の周膜血管と $75 \%$ のリンパ管および 25 \%の神経内脈管（血管とリンパ管）に見られた。神経周膜と神経内の所見を比較すると、神経周膜 脈管へ神経内感染よりも早くらい菌集積が起こる事が示唆される。かかる周膜内栄養脈管への菌集 積は機械的なストレスや炎症の軽度の悪化でも神経内菌血症とそ酸素血症のリスクを大いに高める。 また以上の所見は早期からみられ、特異的ならい菌の末梢神経への局在に、らい菌またはらい菌を 貪食したマクロファージと末梢神経脈管内皮の接着の関与があることを問題提起している。 